UDC 811.111’276.6:34

\title{
MONOMIALS IN ENGLISH FOR LAW
}

\author{
Oksana Chaika \\ PhD (Linguistics), Associate Professor \\ National University of Life and Environmental Sciences of Ukraine \\ (Kyiv, Ukraine) \\ e-mail: oxana.chaika@yahoo.es \\ ORCID: 0000-0002-4317-9456 \\ Yulia Zakatei \\ Master student \\ National University of Life and Environmental Sciences of Ukraine \\ (Kyiv, Ukraine) \\ e-mail: flawless18071998@gmail.com \\ ORCID: 0000-0002-8445-9374
}

The article presents an overview of English for Law as a language for specific purposes and an experimental approach to classifying and analysing the English legal terms from a footing of algebraic linguistics. It is suggested that Ukrainian for Law may currently be viewed as 'understudied' language for specific purposes as opposed to English for Law. At first, the paper presents a general overview of (i) languages for specific purposes and (ii) monomials in linguistics in the light of the term definitions. Then, the research introduces certain structural features of monomials in the legal terminology as exemplified in the English language. The underlying basis refers to the similarities found between an algebraic expression, its components and operations, and a terminological set expression in English for Law as a language for specific purposes. These days skyrocketing development of information technologies and focus on cross-cultural communication in the professional domain require fresh innovative views on the study, with an emphasis on the interdisciplinary. Finally, in everyday interaction experts in law as well as lay-people may hear syntactical patterns of legal terms that arrange in clusters / word combinations, which most frequently consist of two-, three- and multi-components in both English and Ukrainian. The suggested classification may shed some light on to the syntactical structures of the English legal terms, on the one hand, and on the other, it may develop in near future in some distinct product for computer-aided linguistics.

Keywords: language for specific purposes (LSP); English for Law; Ukrainian for Law; a term; a monomial; a polynomial.

Чайка Оксана, Закатей Юлія. Англійські мономіали у фаховій мові права.

У статті представлено огляд англійської мови для права як фахової мови, чи мови особливого призначення, та експериментальний підхід до класифікації та аналізу англійських юридичних термінів, звертаючись до основ алгебрайчної математики у лінгвістииі. Вважається, щзо украӥнська юридична мова в даний час у порівнянні з англійською фаховою мовою права $\epsilon$ «маловивченою» та описаною не в достатній мірі. У вступі Вашій увазі надається загальний огляд понять і визначення власне двох термінів у лінгвістиці - «мова особливого призначення» та «юридичні мономіали (одночлени)». В основній частині статті йдеться про дослідження, щзо аналізує певні структурні особливості мономіалів у юридичній термінології на прикладах юридичних термінів англійської мови права. В основі лежить покликання на подібність між алгебраїчним виразом, його компонентами та операціями та термінологічним 
наукових пошуків $і$ розвідок слугує той факт, щзо в сьогоденні швидкий розвиток інформаційних технологій та орієнтаиія на міжкультурну комунікацію в професійній галузі будь-якої діяльності мовия потребують нових інновачійних поглядів на дослідження з акиентом на міждисииплінарний характер. До того ж, навіть у повсякденні як юристи, судді, прокурори, адвокати, так $і$ посередня особистість зіштовхується із синтаксичними моделями словосполучень, які мають у свойи структурі юридичні терміни. У більшості випадків такі терміни права складаються з двох-, трьох- та багатокомпонентних складових незалежно від мови - англійської чи української.

Ключові слова: мова для конкретних иілей (LSP); англійська мова для права; украӥнська для права; термін; одночлен; багаточлен.

\section{Introduction}

Modern linguistics these days faces a great lot of challenges. It is progressive that studies in corpus linguistics (SCL) focus on (i) the use of corpora throughout language study, (ii) the development of a quantitative approach to linguistics, (iii) the design and use of new tools for processing language texts, etc. (for more detail please browse John Benjamins e-Catalog, especially volumes associated with SCL). It is well- known that computational linguistics looks at the application of computers to the processing of a natural language. However, in our opinion, the coming years would unveil the most important challenges for contemporary linguistics. Such may aim at identifying room for research in the fields of linguistics and psychology, or applied linguistics and interpersonal communication. To be more exact, under a circumstance in which soft skills would play a crucial role and may start even substituting a greater part relevant to technical expertise, it is applied linguistics and various frameworks that may come to the forefront with theories of meaning and conceptualization, psycholinguistics, neurosciences, domains of cognition, etc. In addition, information technologies and IT frameworks can be of utter importance where the innovative ways of considering the term comes into sight.

\section{Language for Specific Purposes}

With the development of business and cross-cultural communication, expansion of economic free zones globally, it turns apparent why a number of scholars may shift their scholar eye to interdisciplinary aspects in the research, by blending applied linguistics and law among the other areas of social and political life [Gales \& Naumova 2018; Chaika 2018; Shuy 2008]. That obviously paves its way into the arena of languages for specific purposes (LSP).

The term language for specific purposes (LSP) has been given a wide range of interpretations as well as known synonymous with a number of other terms, for instance, language for specific purposes [Crouse 2013; Long 2017; Chaika 2017], language for special purposes [Gunnarsson 1997], sublanguage (Kittredge, Richard \& Lehrberger 1982], professional jargon [Hudson 1978], professional discourse and professional communication [Kong 2014; Cheng \& Kong 2009; Nordquist 2017], additional language [Molsing \& Lopes-Perna 2014], etc.

One of the definitions as given by Jonathan Trace, Thom Hudson and James Dean Brown (2015) states that «LSP courses are those in which the methodology, the content, the objectives, the materials, the teaching, and the assessment practices all stem from specific, target language uses based on an identified set of specialized needs» [Trace, Hudson \& Brown 2015, p. 2]. In her paper Language for Specific Purposes: Ukrainian Legal Terms of Obligation, Chaika (2017) adds that the point of LSP is among the other things "to focus on the learners' needs when dealing with education and training, on the one hand, and on the research associated with 
language variation across a required subject field, on the other, thus, making a branch of applied linguistics" [Chaika 2018, p. 52]. It should be mentioned that distinguished scholars view languages for specific purposes as language instruction rather than a branch of applied linguistics - please see works by Norris (2006) and Johns \& Dudley-Evans (1991), etc. At the same time, Oksana Chaika underlines the need in bringing some "theoretical value [of applied (contrastive) linguistics] to the designated essential characteristics of specific purpose instruction" [Chaika 2019, p. 142].

In this paper, we look at the legal terms in the English language and employ the classification suggested by Oksana Chaika in Language for Specific Purposes: Ukrainian Legal Terms of Obligation (2018) [Chaika 2018, p. 52-59]. English, for the purpose of the article, (1) relates to a particular subject field of legal activity, (2) is spoken by a limited number of speakers in contrast with the total number of the Ukrainian speakers, (3) and aims to satisfy the specific communicative needs of such speakers in the professional environment [Chaika 2018, p. 55; Chaika 2019, p. 142]. For example, it is possible to distinguish the terms relevant to the legal domain, that is to say in English for Law: EN under hand and seal, EN a legatory, EN an earliest release date, and let us compare with Ukrainian for Law: UA договірні відносини, UA відновлення подружніх прав, UA закон еtс. Due to the active interchange and the development of economic relations, we follow English for Finance and Ukrainian for Finance: EN assets, EN current liabilities, EN profit and losses, etc., and UA банкрутство 'bankruptcy', UA вторинний ринок 'secondary market', UA оборотній капітал 'current assets', correspondingly. Similarly, the terms fall into the language corpora such as English for Audit and Ukrainian for Audit. For instance, EN control risk, EN due professional care, EN check register etc. And UA висновок експерта 'expert's findings', UA інспектування 'inspection', UA думка аудитора 'an auditor's opinion' etc. Well belong to the domain of audit.

Thus, we may speak about English for Specific Purposes / Ukrainian for Specific Purposes as a functional variety of the language where we highlight the approach rather than a product, without involvement of a certain kind of language and/or methodology.

As regards the above mentioned and an expressed need in a respective methodology, the article advances (i) a methodological toolkit for the classification and (ii) analysis of the terms in English for Law from an interdisciplinary standing that encompass terminology as a field of applied linguistics and algebraic expressions. This area is being studied in connection with computer-assisted linguistics. Moreover, Friedemann Vogel, Professor of Media Linguistics at the University of Freiburg, (Germany), Hanjo Hamann, Senior Fellow at the Max Planck Institute for Research on Collective Goods in Bonn (Germany), and Isabelle Gauer, $\mathrm{PhD}$ seeker in linguistics at the University of Freiburg, give the definition of computer-assisted legal linguistics, by referring to "an area of study ranging from computer-supported qualitative analysis of legal texts to legal semantics and legal socio-semiotics based on big data" [Vogel, Hamann \& Gauer 2017, p. 1341]. The researchers further state that computer-aided legal linguistics requires an interdisciplinary cooperation between lawyers, (computational) linguists, and computer scientists [Vogel, Hamann \& Gauer 2017, p. 1341].

\section{Monomials in Linguistics}

Following Oksana Chaika (2019), languages for specific purpose may be viewed crucial to drive the development of global economies and advance new digital technologies [Chaika 2019, p. 101]. For the purpose of the article, the focus is 
going to be on English for Law in general and the monomial variables in the English legal terminology, in particular. To be more specific, Chaika (2019) in her article Monomials Variables in English Audit Terminology compares the terms and/or terminological set expressions in English for Audit as an LSP and the algebraic expressions in mathematics. Next, the author underlines that "a key way to schematize the analytic methodology is in terms of relationship between the term and components of the term, where such term features a more complex nature, with the further focus on the first subcategory in the proposed classification, taken the restricted title" [Chaika 2019, p. 101].

By aggregating Ferdinand de Saussure's theory that linguistic entities are parts of a system and are defined by their relations to one another within that system [Saussure 1916, p. 108], on the one hand, and that of Chomsky (1994) with language as the construction of sentences that can be generated using transformational grammars [Chomsky 1994], on the other, we may consider the connection between algebraic expressions in mathematical logic and linguistics.

In mathematics, "monomials are introduced mostly through lists of properties that are both necessary and sufficient" [Bolondi, Ferretti \& Maffia 2018, p. 7] as opposed to polynomials - "a polynomial is defined as the algebraic sum of monomials, but the classification of monomials as polynomials is justified by considering the sum of a monomial and the null monomial" [Bolondi, Ferretti \& Maffia 2018, p. 8].

Therefore, adopting the methodological toolkit for the classification and analysis of the English terms in the audit domain [Chaika 2019, p. 104], let us classify the most frequently used terms in English for Law as based on their structure:

(1) Monomials, and

(2) Polynomials.

For the purpose of the article, a monomial terminological set expression in English for Law (a monomial in the English legal terminology, or an English monomial legal term, or a monomial in English for Law) means only one term, which can be extended with a modifier / modifiers or unextended. A polynomial terminological set expression (a polynomial in the English legal terminology, or an English polynomial legal term, or a polynomial in English for Law) means an addition of two or more terms, which can be extended with a modifier / modifiers or remain unextended, respectively [Chaika 2019, p. 104].

The research conducted and a deeper analysis of the structure of the English legal terms provides sufficient ground to state that the most frequently used terms in English for Law may fall under the classification by Oksana Chaika, according to which the structure of a term / terminological set expression may be compared with the algebraic expressions - monomials and polynomials [Chaika 2019, p. 101]. To this extent, the classification of monomials and polynomials in the English legal terminology may envelope as below:

1. Monomials in English for Law:

1.1. The simple term that comprises one word only, for instance: EN cause 'the preceding event that made the event in question occur' [Black 1968, p. 15] - a monomial in one variable cause.

1.2. The compound term that may consist of two components (algebraic terms):

1.2.1. Adjective + Noun (in singular), for instance: EN criminal law 'a special type of law that protects people and the 
things that they own' [Mario \& Richard 1991, p. 42] - a monomial in two variables (1) criminal, and (2) law.

1.2.2. Adjective + Noun (in plural), for instance: EN illegal acts 'acts that are not legal' - a monomial in two variables (1) illegal, and (2) acts.

1.2.3. Noun + Noun, for instance: EN bail presumption 'a law that guides the judge so the judge knows when s/he will give bail, and when s/he will not give bail to a defendant' [Mario \& Richard 1991, p. 25] - a monomial in two variables (1) bail, and (2) presumption.

1.2.4. Noun + Preposition + Noun, for instance: EN cause of action 'a suit brought because the other party exhibited an unreasonable and reckless disregard for the rights of the one suing' [Black 1968, p. 15] - a monomial in two variables (1) cause, and (2) action.

1.3. The compound term that may consist of three components (terms):

1.3.1. Adverb + Adjective + Noun, for instance: EN fully suspended sentence 'one way a judge will punish (sentence) an offender' [Mario \& Richard 1991, p. 102] - a monomial in three variables (1) fully, (2) suspended, and (3) sentence; EN especially dangerous crime - a monomial in three variables (1) especially, (2) dangerous, and (3) crime.

1.3.2. Noun + preposition + Adjective + Noun, for instance: EN restitution of conjugal rights [English-Russian terms 2003, p. 301] - a monomial in three variables (1) restitution, (2) conjugal, and (3) rights.

1.3.3. Adjective + Noun + Noun, for instance: EN earliest release date 'when a judge sentences an offender to a nonparole period, the earliest release date is the first day a prisoner is allowed to come out of prison on parole' [Mario \& Richard 1991, p. 48] - a monomial in three variables (1) earliest, (2) release, and (3) date.

1.3.4. Noun + Noun + Noun, for instance: EN home detention order 'one way a judge will punish (sentence) an offender' [Mario \& Richard 1991, p. 56] - a monomial in three variables (1) home, (2) detention, and (3) order.

1.4. Multicomponent monomials - syntactical structures:

1.4.1. Verb + Noun + Preposition + Noun + Preposition + Noun ${ }_{2}$ for instance: EN qualify a witness by the obligation of an oath [1];

1.4.2. Noun + Preposition + Participle $\mathbf{I}+$ Adjective + Noun, for instance: EN regulations on handling secret documents [Юридична енциклопедія 2003];

1.4.3. Noun + Preposition + Noun + Preposition + Adjective +

Noun, for instance: EN safeguards for the defense in criminal procedure, EN status of limitation in criminal cases [Юридична енциклопедія 2003]; 
1.4.4. Verb + Noun + Preposition + Adjective + Noun, for instance: EN seek a relief in an appellate court [Юридична енциклопедія 2003];

1.4.5. Adjective + Noun + Preposition + Verb + Noun, for instance: EN sole authority to ratify treaties [Юридична енциклопедія 2003];

1.4.6. Adverb + Adjective + Adjective + Noun, for instance: EN specially dangerous habitual criminal [Юридична енциклопедія 2003];

1.4.7. Noun + Preposition + Adjective + Noun + Noun, for instance: EN survivor of a genuine suicide part [Юридична енциклопедія 2003];

1.4.8. Noun + Verb + Adjective + Noun, for instance: EN failure to perform a legal duty [Юридична енциклопедія 2003];

1.4.9. Participle II + Noun + Noun + Noun, for instance: EN computerized fingerprint search system [Юридична енциклопедія 2003];

1.4.10. Adjective + Noun + Preposition + Adjective + Noun, for instance: EN Department for struggle against economic crimes [Юридична енциклопедія 2003];

1.4.11. Noun + Preposition + Adjective + Noun + Conjunction + Noun, for instance: EN curtailment of democratic rights and freedoms [Юридична енциклопедія 2003];

1.4.12. Noun + Preposition + Adjective + Adjective + Noun, for instance: EN exterritorialy of foreign diplomatic missions [Юридична енциклопедія 2003];

1.4.13. Adverb + Participle II + Noun + Preposition + Noun, for instance: EN generally accepted principles of law [Юридична енциклопедія 2003];

1.4.14. Adjective + Noun + Preposition + Participle $\mathbf{I}+$ Participle II + Noun, for instance: EN district administration for combating organized crime [Юридична енциклопедія 2003, p. 453].

2. Polynomials (binomials) in English for Law:

- EN aid and abet [Espenschied 2010, p. 164] - a binomial in two variables (1) aid, and (2) abet.

- EN deem and consider [Espenschied 2010, p. 164] - a binomial in two variables (1) deem, and (2) consider.

- EN due and reasonable care "care which reasonably prudent man would exercise under circumstances' [English-Russian terms 2003, p. 589] - a binomial in three variables (1) due, (2) reasonable, and (3) care.

- EN power and authority [Espenschied 2010, p. 164] - a binomial in two variables (1) power, and (2) authority.

- EN true and correct [Espenschied 2010, p. 164] - a binomial in two variables (1) true, and (2) correct.

\section{Conclusion}

As exemplified in the above provided classification and the structural analysis of the monomials in English for Law, i. e. legal terminological set expressions, the parallel is drawn between the systematic relations in an algebraic expression and 
those in a terminological set expression in the English legal terminology. The focus is with the relations / difference between monomial variables, which determine the key concept of the term itself. Although the present study is being developed and monitored when fitting to different corpora in applied linguistics, and the contents to the introduction of the proposed classification limits to a small number of illustrations, we believe that the approach may be used for further study and in future be employed in the computer-aided linguistics. At this stage, we have come to the four groups of the monomials in English for Law given their structure, (i) the simple monomial, (ii) the compound monomial that consists of two components, (iii) the compound monomial that contains three elements in its structure, and (iv) the multicomponent monomial that reflects a syntactical pattern. The study is yet to reveal what conceptual relations may occur within the complex term. Any feedback is warmly welcome at oxana.chaika@yahoo.es.

\section{LITERATURE} $736 \mathrm{c}$.

Юридична енциклопедія (2003). В 6 т. Ю. С. Шемшученко (відп. ред.) та ін. Київ,

Black, H. C. (1968). Black's Law Dictionary. $4^{\text {th }}$ Ed. Rev. St. Paul, 1882 p.

Bolondi, G., Ferretti, F. \& Maffia, A. (2018). Monomials and polynomials: the long march towards a definition. [In:] Teaching Mathematics and Its Applications, pp. 1-12.

Chaika, O. (2018a). Language for Specific Purposes: Ukrainian Legal Terms of Obligation. [In:] Восточнославянские языки и литературы в европейском контексте. Сб. науч. трудов. Е. Е. Иванов (ред.). Могилев, с. 52-59.

Chaika, O. (2018b). Ukrainian for Law and Portuguese for Law as 'Understudied' Languages for Specific Purposes. [In:] Філологічний часопис, вип. 1 (11), с. 118-127.

Chaika, O. (2019a). A Dive for Determinants of Ukrainian and English for Audit and Accounting as Languages for Specific Purposes. [In:] Людина. Комп'ютер. Комунікаиія. Збірник наукових праць. О. П. Левченко (ред.). Львів, 1 електрон. опт. Диск (CD-ROM). ISBN 978-966-941-389-5.

Chaika, O. (2019b). Monomial Variables in English Audit Terminology. [In:] International journal of philology, vol. 10, № 1, p. 100-108.

Cheng, W. \& Kong, K. C. C. (2009). Professional communication: Collaboration between academics and practitioners. Hong Kong, pp. 3-16.

Chomsky, N. (1994). Translated as Structures Syntaxiques. France, 140 p.

Crouse, D. (2013). Language for Specific Purposes in the $21^{\text {st }}$ Century. [In:] The Language Educator, April, p. 32-35.

de Saussure, F. (1916). The Course of General Linguistics (Cours de linguistique générale). Paris, $336 \mathrm{p}$.

English-Russian terms on civil law and law of civil procedure (2003). Compiled by S. D. Oskina. Omsk, 350 p.

Espenschied, L. E. (2010). Eliminate clutter and redundant language. Eliminate common doublets and triplets. [In:] Contract Drafting: Powerful Prose in Transactional Practice. ABA Fundamentals. Chicago, pp. 164-165.

Gales, T. \& Naumova, L. (2018). Language and Law [Electronic resource]. URL: https://www.oxfordbibliographies.com/

Gunnarsson, B. L. (1997). The Construction of Professional Discourse (Language in Social Life). Longman, 328 p.

Hudson, K. (1978). The Jargon of the Professions. London, 146 p.

Johns, A. M. \& Dudley-Evans, T. (1991). English for Specific Purpose: International in Scope, Specific in Purpose. [In:] Tesol Quarterly, vol. 25, № 2, pp. 297-314.

Kittredge, R. \& Lehrberger, J. (1982). Sublanguage: Studies of Language in Restricted Semantic Domains. Berlin, 240 p.

Kong, K. (2014). Learning through workplace communication: An evaluation of existing resources in Hong Kong. [In:] English for Specific Purposes, vol. 34, pp. 68-78. 
Long, M. K. (2017). Language for Specific Purposes: Trends in Curriculum Development. Washington, pp. 13-34.

Mario, M. C. \& Richard, H. G. (1991). Dictionary of terms and legal definitions related to hazardous medical and solid wastes. New York, 148 pp.

Mosling, K. \& Lopes-Perna C. (2014). Research and Teaching in Portuguese for Specific Purposes. [In:] BELT Journal. Porto Alegre, vol. 5, n. 2, pp. 1-7.

Nordquist, R. (2017). What is Communication? Thoughtco. [Electronic resource]. URL : https://www.thoughtco.com.

Norris, J. \& Ortega, L. (2006). Synthesis Research on Language Learning and Teaching. Amsterdam, IX $+349 \mathrm{p}$.

Shuy, R. W. (2008). Fighting over words. Language and civil law cases. Oxford, VII +246 p.

The Plain English Legal Dictionary (Northern Territory Criminal Law) (2015). 122 p.

Trace, J., Hudson T. \& Brown, J. D. (2015). Developing Courses in Languages for Specific Purposes. NFLRC Resources on ScholarSpace. Honolulu, 303 p.

Vogel, V., Hamann, H. \& Gauer, I. Computer-Assisted Legal Linguistics: Corpus Analysis as a New Tool for Legal Studies. [In:] Law \& Social Inquiry, vol. 43, issue 4, pp. 1340-1363.

Подано до редакиії 26.09.2019 року

Прийнято до друку 24.10.2019 року 